\title{
BIODIVERSITY CONSERVATION: GEOSYNPHYTOSOCIOLOGY AS A TOOL OF ANALYSIS AND MODELLING OF GRASSLAND SYSTEMS
}

\author{
Andrea CATORCI*, Sabrina CESARETTI* \& Renata GATTI*
}

\begin{abstract}
The study site is located along the Umbria-Marches Apennine (central Italy). Following a series of research topics, the aims and objectives of this paper are to present the tested process of forage resources modelling at a large scale in a pastoral system in order to define essential management and decision making aimed on biodiversity conservation.

The analytical process is based on correlation between phytosociological and agro-zootechnical analysis. This approach allows one to extend any type of heterogeneous data, provided this is in any way correlated to the intrinsic characteristics of the plant community, can be interpolated to the whole polygon and therefore to all polygons referring to the same phytosociological unit. In terms of planning and application, the results of phytosociological modelling are much more useful when integrated in a database (GIS), in which the different information levels, based on hierarchical criteria, are simulated in multiple polygon segmentations.

In particular, this method allows one to obtain a first general overview of the forage resource using the theoretical data linked to the phytosociological interpretation of the territory. Subsequently, this overview can be enhanced with actual quantitative data, offering also a qualitative dimension coming from the phytosociological aspects.

Key words: Geosynphytosociological modelling, plant community, forage resource, carrying capacity, grazing management, biodiversity conservation.
\end{abstract}

\section{Izvleček}

Raziskovano območje se nahaja vzdolž Apeninov v območju Umbria-Marke (osrednja Italija). V članku so testirali modeliranje krmne vrednosti na velikem območju v travniškem sistemu in določitli ključne načine gospodarjenja in odločanja zaradi ohranjanja biodiverzitete.

Analitični proces temelji na korelaciji med fitocenološko in agro-zootehniško analizo. Ta pristop omogoča uporabo katerihkoli heterogenih podatkov, če so ti v povezavi z bistvenimi lastnostmi rastlinske združbe in jih lahko posplošimo na celoten poligon združbe oziroma na vse poligone iste fitocenološke enote. S stališča načrtovanja in uporabnosti so rezultati fitocenološkega modeliranja uporabnejši, kadar jih vključimo v podatkovno bazo (GIS). V njej lahko simuliramo različne členitve v poligone s pomočjo različnih informacijskih nivojev, ki temeljijo na različnih hierarhičnih merilih.

Metoda omogoča prvi splošni pregled krmnih vrednosti s pomočjo teoretičnih podatkov, povezanih s fitocenološko interpretacijo območja. Dodatno lahko ta pregled izboljšamo z dejanskimi kvantitativnimi podatki, s pritegnitvijo fitocenološkega vidika pa pridobimo tudi kvalitativno dimenzijo.

Ključne besede: Geosinfitosociološko modeliranje, rastlinske združbe, krmna vrednost, nosilna kapaciteta, paša, ohranjanje biodiverzitete.

\section{INTRODUCTION}

Grassland ecosystems represent a fundamental resource of plant species richness. For example, the Umbria-Marches Apennine (central Italy) occupy only $8 \%$ of the Marches Region but contain $35 \%$ of the total flora (Tardella et al. 2007).

The need to conserve such plant biodiversity in these ecosystems is confronted with socio-economic issues and animal breeding systems which,

\footnotetext{
* Department of Environmental Science, Section of Botany and Ecology, University of Camerino via Pontoni 5 - 62032 Camerino (MC) Italy. E-mail: andrea.catorci@unicam.it, sabrina.cesaretti@unicam.it, renata.gatti@unicam.it
} 
as is the case of most European grassland systems, have experienced a significant decline in productive activities, as well as a substantial reduction of grazing.

The result of this situation is a modification of plant communities, whether in terms of composition of the various phytocenoses or the landscape mosaic, by activation of the dynamic processes of substitution (Persson 1984, Francalancia et al. 1995, Bakker 1998, Pott 1998, Biondi 2001, Bonanomi \& Allegrezza 2004, Foglia et al. 2007).

For this reason it is absolutely necessary to prepare an investigative framework aimed at planning biodiversity grazing management. However, this objective is difficult to achieve because within a certain bio-geographical area the composition and plant species richness of a pastoral landscape are correlated to multiple factors: a) the pattern of plant communities connected to a mosaic of environmental factors which act on a landscape scale, such as climate and geology (Ercole et al. 2005, Biondi et al. 2006, Cutini et al. 2007); b) the pattern of seasonal conditions, which are interrupted by topographic (exposure and slope) and pedological variations (Miles 1985, Grime 2001, Miles 2004, Agnelli et al. 2008), which define the ecological space of each plant community; c) the micro pattern created by localised variations, mainly soil chemical and physical properties (differences in AWC, Nitrogen content, $\mathrm{pH}$, etc.), which interfere with the differentiation of plants within the plant community (Filesi et al. 2004); d) the intensity of grazing, which acts on the plant population scale and in this case corresponds to the so-called intermediate disturbance level, which guarantees maximum plant species richness (Grime 1973) with regard to the site's environmental characteristics and its biogeographical history.

Therefore, grasslands are complex ecosystems, which constitute numerous abiotic and biotic elements whose interactions vary in space and time (Tainton et al. 1996). In order to be fully understood, the multidimensional complexity of ecological grassland systems must be divided into organisational levels, each containing a few interacting unities. With this method the reciprocal relationships and the connectivity between the highest and the lowest organisational levels can be modelled (Tainton et al. 1996). This analytical process can only result from a hierarchical interpretation of the interacting factors of a territory in varying spatial-temporal intervals (King 1977, Allen \& Starr 1982, O’Neill \& King 1998, Blasi et al. 2000, Blasi et al. 2003). Furthermore, once the scale of analysis is changed, each element becomes part of a superior element, thus containing multiple systems of inferior rank (Farina 2001).

In order to obtain applicable documents, the hierarchical levels that constitute an "ecological landscape" of a territory must be defined, both conceptually and spatially. In this regard, using the methods and concepts of dynamic-catenal phytosociology (Ozenda 1982, Géhu et al. 1991, Rivas-Martinez 2005) can be a useful basis, particularly if these data are expressed by means of phytosociological maps (Pedrotti 2004).

This opportunity is inherent to the fact that the phytosociological modelling of the landscape of a territory is based on floristic, ecological, statistical and hierarchical criteria (Rivas Martinez 2005). This assumption makes it possible to map families of polygons within which physiognomic, floristic, dynamic and ecological characteristics are most likely to present a reduced variability. For this reason any data carried out from an experimental plot (e.g. productivity), provided this is in any way correlated to the intrinsic characteristics of the plant community (plant composition, architectonic structure, dynamic tendencies, bioclimatic properties, phenological rhythms, etc.), can be applied to the whole polygon and therefore to all polygons referring to the same phytosociological unit.

In addition, the syndynamic and geo-syndynamic characterization of a territory indirectly allows the geographic defining of varying bioclimatic indices, i.e. stresses induced by cold and aridity (Cano et al. 1997), which have a considerable influence on certain important parameters of forage resources in a grassland system.

This approach can therefore allow for the design of models aimed at representing pastures and their respective functions also in very large territories. Models have become powerful tools for translating the complexity of reality into meaningful concepts. They have the potential to supply substantial management support in the form of decision support models and expert systems (WallisDe Vries \& Van de Koppel 1998).

Different types of models may be put to different uses: explanatory models unravel the mechanism processes; predictive models yield quantitative predictions of future development after thorough validation; integrated functional models ease the difficult task of finding an optimal trade-off between generality and specificity 
in response to the manager's questions and under constraints of available knowledge and funding. The choice to review models is prompted by their capacity to synthesize the knowledge and experience, and to reach new insights.

In terms of planning and application, the results of phytosociological modelling are much more useful when integrated in a Geographic Information System (GIS) database, in which the different information levels, based on hierarchical criteria, are simulated in multiple polygon segmentations (Blaschke 2001).

Based on these scientific-cultural assumptions, the aims and objectives of this paper are to present the modelling process of forage resources in a large scale pastoral system in order to define essential management efforts aimed at biodiversity conservation.

\section{MATERIALS AND METHODS}

\subsection{Conceptual Logigs}

In order to carry out the management plan it is necessary to perform in-depth forage resource characterization and modelling (Hodgson \& Hillius 1998). This entails a complex cognitive process, which is impossible to complete in one season. This process requires several years and thorough planning on deciding which data to collect and when. Therefore, a research plan must be created including the input of results into a database.

The research presented here aims at underlining the path followed for the establishment of an exclusive database, as well as the various evaluated botanical-agronomical and ecological parameters.

Table 1: Main bioclimatic characteristics of the study area

Tabela 1: Glavne bioklimatske značilnosti preučevanega območja.

\begin{tabular}{|c|c|c|c|c|c|c|c|c|c|c|}
\hline $\begin{array}{c}\text { Bioclimatic } \\
\text { belt }\end{array}$ & $\begin{array}{l}\text { Altitudinal } \\
\text { range m } \\
\text { a.s.l. }\end{array}$ & $\begin{array}{c}\text { Average } \\
\text { annual } \\
\mathbf{T}^{\circ} \mathrm{C}\end{array}$ & $\begin{array}{c}\text { Average } \\
\text { Annual P } \\
\text { mm }\end{array}$ & $\begin{array}{c}\mathrm{N}^{\circ} \text { of } \\
\text { months } \\
\text { with } \\
\text { annual } \\
\mathrm{T}<10^{\circ} \mathrm{C}\end{array}$ & $\begin{array}{c}\mathrm{N}^{\circ} \text { of } \\
\text { months } \\
\text { with tmin } \\
<0^{\circ} \mathrm{C}\end{array}$ & $\begin{array}{c}\text { Thermo- } \\
\text { type }\end{array}$ & $\begin{array}{c}\text { Ombro- } \\
\text { type }\end{array}$ & $\begin{array}{c}\text { Drought } \\
\text { stress } N^{\circ} \\
\text { months }\end{array}$ & $\begin{array}{c}\text { Cold } \\
\text { stress } \mathrm{N}^{\circ} \\
\text { months }\end{array}$ & $\begin{array}{c}\text { Length } \\
\text { of growing } \\
\text { period } \\
\left(\mathrm{N}^{\circ} \text { days }\right. \\
\text { with tmin } \\
\left.>6^{\circ} \mathrm{C}\right)\end{array}$ \\
\hline $\begin{array}{c}\text { Upper } \\
\text { Mesotemperate }\end{array}$ & $450-1000$ & $11-13$ & $850-1100$ & $5-6$ & $1-2$ & $\begin{array}{c}\text { Upper } \\
\text { Mesotemperate }\end{array}$ & $\begin{array}{l}\text { Lower } \\
\text { Humid }\end{array}$ & 0 & $6-7$ & $180-210$ \\
\hline $\begin{array}{c}\text { Lower } \\
\text { Supratemperate }\end{array}$ & $1000-1450$ & $9-11$ & $1100-1300$ & $6-7$ & $2-3$ & $\begin{array}{c}\text { Lower } \\
\text { Supratemperate }\end{array}$ & $\begin{array}{l}\text { Upper } \\
\text { Humid }\end{array}$ & 0 & $7-8$ & $150-180$ \\
\hline $\begin{array}{c}\text { Upper } \\
\text { Supratemperate }\end{array}$ & $1450-1900$ & $7-9$ & $1300-1500$ & $7-8$ & $3-4$ & $\begin{array}{c}\text { Upper } \\
\text { Supratemperate }\end{array}$ & $\begin{array}{l}\text { Lower } \\
\text { Iperhumid }\end{array}$ & 0 & $8-9$ & $120-150$ \\
\hline
\end{tabular}

\subsection{Study Area}

The study site is located along the Apennine ridge that characterizes the interior of central Italy; the Umbria-Marches Apennine constitutes two parallel ridges with a NW-SE trend. Among these ridges, the western peaks reach altitudes of 1200 to 1500 metres, whereas most of the eastern peaks reach altitudes of 800 to 1200 metres. Towards the south, the two ridges merge with the Sibillini Mountain chain, not included in this study, whose peaks generally exceed 2000 metres in altitude.

In terms of geology the Umbria-Marches Apennine is characterised by predominantly calcareous lithotypes (Regione Marche 1991). The morphology of this mountain chain is characterised by steep slopes, cut by deep valleys, whereas the summits present weak slopes.

In terms of pedology, the aforementioned geomorphological areas are differentiated by the presence of soil catenas (Cremaschi \& Rodolfi 1991). These are characterised by the presence of less evolved and shallow soils found gradually moving from more conservative morphologies (flat surfaces) toward steeper morphologies or from northern to southern exposure (Pieruccini 2007).

With regard to the bioclimatic area, the study is comprised within the following bioclimatic belts (Biondi et al. 1995, Orsomando et al. 1999, Catorci et al. 2007a): Upper Mesotemperate, Lower Supratemperate and Upper Supratemperate. The principal bioclimatic characteristics of the aforementioned levels are summarised in Table 1. 


\subsection{DAta Gollection}

For the purposes described in the introduction, the first step in the research plan was to characterise grassland vegetation using the phytosociological method (Braun-Blanquet 1931) combined with the most recent information on synphytosociology and geosynphtosociology (Géhu \& Rivas-Martinez 1981, Theurillat 1992, Biondi 1996, Biondi et al. 2004a). Geobotanical maps were used as guidelines (Pedrotti 2004).

Subsequently, the distributions of the various syntaxa were modelled using numerous transects in the field and multivariate analyses (Podani 2001), Principle Component Analysis (PCA) in particular.

Using ARCGIS 9.0, the Vegetation Map of grassland communities was created, which also allowed activation of the database.

Following the guidelines of dynamic phytosociology, sigmeta (vegetation series) as well as geosigmeta (geoseries) (Rivas-Martinez 2005) (belonging to the different syntaxa) were identified and thus the management levels defined (isofunctional landscape cells) as described by Géhu (1988).

The agronomical and zootechnical aspects of each studied phytosociological unit were associated with the following parameters, collected throughout a 3 year period: pastoral value (Tomaselli 1956, Delpech 1960, Daget \& Poissonet 1969, Corrall \& Fenlon 1978, Sarno et al. 1989, Bagella 2001, Cavallero et al. 2002, Roggero et al. 2002, Bagella \& Roggero 2004); maximum and seasonal productivity (Floret \& Le Floch 1983, Gratani et al. 1999); theoretical utilisation coefficient of phytomass (Gatti \& Catorci 2005, Gatti et al. 2005); theoretical carrying capacity (Bittante et al. 1990, 1993); bromatological characterization (Grayson 1999, Sánchez Rodríguez et al. 2006). The required database was obtained partly from Gatti \& Catorci (2007) and Gatti et al. (2007b/c), partly by collecting data in the field as an addition to data already published.

The formula used to calculate the pastoral value is:

$$
\mathrm{Pv}=0,2 \times \sum_{i=1}^{\mathrm{n}} \mathrm{CSP}_{i} \times \mathrm{Is}_{i}
$$

where $\mathrm{Pv}$ is the pastoral value of the community; $\mathrm{n}$ is the number of species in the community; $\mathrm{CSP}_{i}$ is the specific contribution of the presence of $i$ species and Is is its specific index.
The productivity of the studied syntaxa was analysed by means of fortnightly grass cutting in permanent plots, excluding pastures for domestic animals; the seasonal productivity of each syntaxon was calculated in $\mathrm{g} / \mathrm{m}^{2}$ of dry matter, adding the forage productivity at maximum vegetative development with that of successive re-growth collected with the fortnightly grass cutting within the same plot.

In order to determine the theoretical carrying capacity, the complex dry matter was transformed into theoretical forage units (FU/ha per year). According to Bittante et al. (1993) $1 \mathrm{~kg}$ of dry matter of natural polyphyletic grassland has an approximate nutritional value of $0.69 \mathrm{FU}$. This value is used as a basis to estimate the livestock units (LSU) that the pasture is able to sustain (theoretical carrying capacity, LSU/ha).

The formula used is:

$$
L S U / h a=\left(\frac{F U / h a \text { anno }}{\frac{3000}{365} \times D}\right) \times C u_{t} \times\left(1+\frac{C R S_{\text {tot }}}{1000}\right)
$$

where $\mathrm{D}$ is the number of days of permanent grazing on the pasture (summer pasture), which is generally 150 days in the Apennines and $\mathrm{Cu}_{\mathrm{t}}$ is the theoretical utilisation coefficient, calculated using the formula:

$$
C u_{t}=\frac{\sum_{i=1}^{N} C R S_{i, I s \neq 0}}{C R S_{\text {tot }}}
$$

where CRS $S_{I s \neq 0}$ is the coefficient of specific presence of palatable plants (species with Is $\neq 0$ ) and CRS tot is the coefficient of specific presence of the plant communities, estimated on the basis of phytosociological data.

With the calculated pastoral value, the productivity and theoretical carrying capacity of each plant community, the optimal class number (C) and their relative size were obtained based on $\mathrm{N}$ observations, according to the formula described by Sturges (1926).

With the aim of obtaining data for zootechnical purposes, a bromatological analysis was carried out on the main syntaxa present in the study area using the method described by Weende and subsequent additions (Bittante et al. 1990). 
It is hereby possible to determine the chemical composition (moisture content, ash content, unrefined proteins, unrefined fats, unrefined cellulose, extracts lacking nitrogen), an essential step in nutritional assessment. This allows for characterization of the various nutritional substances as well as accurate definition of the system's carrying capacity.

Finally, modelling of certain characteristics of forage resources was carried out using productivity data and bioclimatic characteristics. These characteristics were correlated to the different seasonal phases, such as determination of the peak in production for each syntaxon, presence and duration of a potential summer productivity stasis (senescence); duration of vegetative phase.

\section{RESULTS}

\subsection{Geosynphytosociological CHARACTERIZATION}

In this study, the grassland ecosystems represent a well defined phytosociological system. Geoformations, exposures and altitudinal gradients play an important role in defining the characteristics of the pastoral landscape.

In particular, 14 syntaxa contained mainly within the alliances Phleo ambigui-Bromion erecti, Ranunculo-Nardion strictae and Seslerion apenninae have been detected (Biondi \& Ballelli 1995, Baldoni et al. 1996, Allegrezza 2003, Biondi et al. 2004b, Biondi et al. 2005, Catorci et al. 2007b). The main ecological-spatial characteristics of these syntaxa are summarised in Table 3, whereas Table 2 shows their subdivision in the respective sigmeta and geosigmeta.

Table 2: Subdivisions of the analysed syntaxa in their respective sigmeta and geosigmeta

Tabela 2: Členitev obravnavanih sintaksonov ter njihovih sigmetov in geosigmetov.

\title{
UPPER MESOTEMPERATE BELT GEOSIGMETUM
}

Scutellario columnae-Ostryo carpinifoliae violo reichenbachianae sigmetosum

Brizo mediae-Brometum erecti cynosuretosum cristati (Northern slopes)

Colchico lusitani-Cynosuretum cristati (Flat valleys)

Cytiso sessilifolii-Querco pubescentis sigmetum

Asperulo purpureae-Brometum erecti asperuletosum purpureae (Southern slopes)

Asperulo purpureae-Brometum erecti onobrychidetosum viciifoliae (Southern slopes)

Stipo apenninicolae-Seslerio juncifoliae seslerio juncifoliae sigmetosum

Stipo apenninicolae-Seslerietum juncifoliae seslerietosum juncifoliae (Watershed)

Carici sylvaticae-Quercetum cerridis

Brizo mediae-Brometum erecti danthonietosum alpinae (Top)

\section{LOWER SUPRATEMPERATE BELT GEOSIGMETUM \\ Lathyro veneti-Fago sylvaticae lathyro veneti sigmetosum \\ Brizo mediae-Brometum erecti brizetosum mediae (Northern slopes) \\ Brizo mediae-Brometum erecti pöetosum alpinae (Top) \\ Brizo mediae-Brometum erecti festucetosum commutatae (Northern slopes) \\ Colchico lusitani-Cynosuretum cristati (Flat valleys)}

Scutellario columnae-Ostryo carpinifoliae seslerio nitidae sigmetosum

Potentillo cinereae-Brometum erecti potentilletosum cinereae (Southern slopes)

Potentillo cinereae-Brometum erecti caricetosum humilis (Southern slopes)

Seslerio nitidae-Brometum erecti (Southern slopes)

Carici humilis-Seslerio apenninae sigmetum

Carici humilis-Seslerietum apenninae (Watershed)

\author{
HIGHER SUPRATEMPERATE BELT GEOSIGMETUM \\ Cardamino kitaibelii-Fago sylvaticae sigmetum \\ Filipendulo vulgaris-Trifolietum montani gentianelletosum columnae (Northern slopes) \\ Carici humilis-Seslerio apenninae sigmetum \\ Carici humilis-Seslerietum apenninae (Watershed)
}




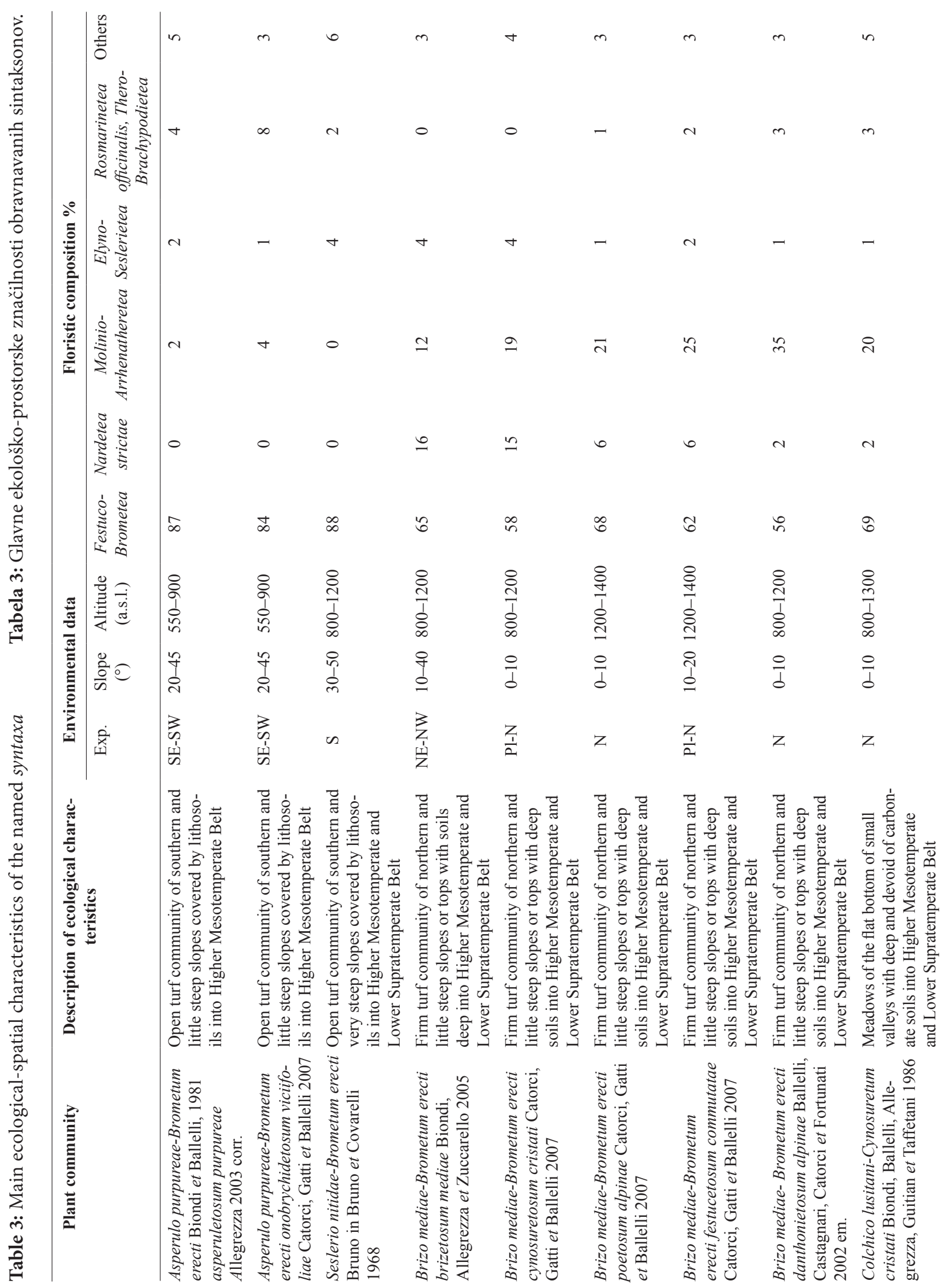




\begin{tabular}{|c|c|c|c|}
\hline$r$ & in & - & 0 \\
\hline$\simeq$ & in & - & $\nabla$ \\
\hline in & $N$ & F & $\approx$ \\
\hline- & $\nabla$ & - & - \\
\hline 0 & 0 & - & 0 \\
\hline$\approx$ & চ & in & $\hat{\sigma}$ \\
\hline 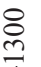 & 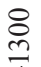 & $\stackrel{8}{I}$ & 8 \\
\hline § & 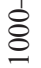 & §ి & $\stackrel{8}{8}$ \\
\hline$n$ & $n$ & $\stackrel{?}{P}$ & $n$ \\
\hline \& & 우 & $\stackrel{\circ}{\circ}$ & 아 \\
\hline$\sim s$ & $n$ & $\begin{array}{l}3 \\
n \\
\text { 离 } \\
0 \\
\text { ñ }\end{array}$ & 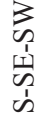 \\
\hline
\end{tabular}

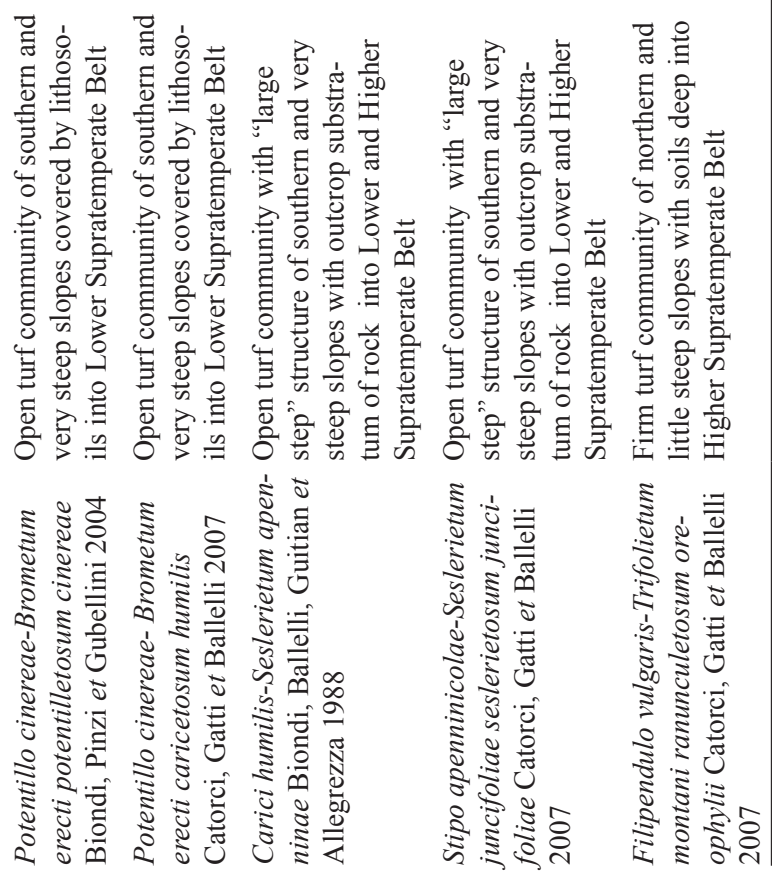

\subsection{Agro-ZOOTEGHNICAL CHARACTERIZATION}

\subsubsection{Pastoral value}

The pastoral value results are presented in Table 4. It is shown that the pastoral values of the xeric plant communities found in summit areas are lower than those found on Southern slopes, as are the values of Northern mesophilic plant communities. These show lower pastoral values than the syntaxa typically found in flat areas of valleys or summits.

Table 4: Pastoral values (means) and relative reference classes for each syntaxon

Tabela 4: Krmne vrednosti (povprečne) in relativni referenčni razred za posamezni sintakson.

\begin{tabular}{|c|c|c|}
\hline PLANT COMMUNITY & 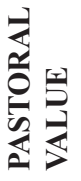 & 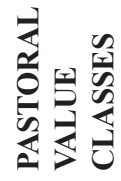 \\
\hline is-Seslerietum apenninae & 12,45 & 1 \\
\hline Stipo apenninicolae-Seslerietum & 12,70 & 1 \\
\hline
\end{tabular}

juncifoliae seslerietosum

juncifoliae

Seslerio nitidae-Brometum erecti $\quad 12,86 \quad 1$

Potentillo cinereae-Brometum erecti $\quad 12,88 \quad 1$ caricetosum humilis

Potentillo cinereae-Brometum erecti $\quad 15,42 \quad 1$ potentilletosum cinereae

Brizo mediae-Brometum erecti $\quad 18,46 \quad 2$ festucetosum commutatae

$\begin{array}{lll}\text { Filipendulo vulgaris-Trifolietum } & 18,52 \quad 2\end{array}$ montani gentianelletosum columnae

Asperulo purpureae-Brometum erecti $\quad 20,69 \quad 2$ onobrychidetosum viciifoliae

Brizo mediae-Brometum erecti $21,07 \quad 3$ cynosuretosum cristati

Brizo mediae-Brometum erecti $\quad 21,32 \quad 3$ brizetosum mediae

Asperulo purpureae-Brometum erecti $\quad 21,70 \quad 3$ asperuletosum purpureae

Brizo mediae-Brometum erecti $\quad 21,74 \quad 3$ poetosum alpinae

Brizo mediae-Brometum erecti $\quad 26,66 \quad 4$ danthonietosum alpinae

Colchico lusitani-Cynosuretum $\quad 33,04 \quad 5$ cristati 


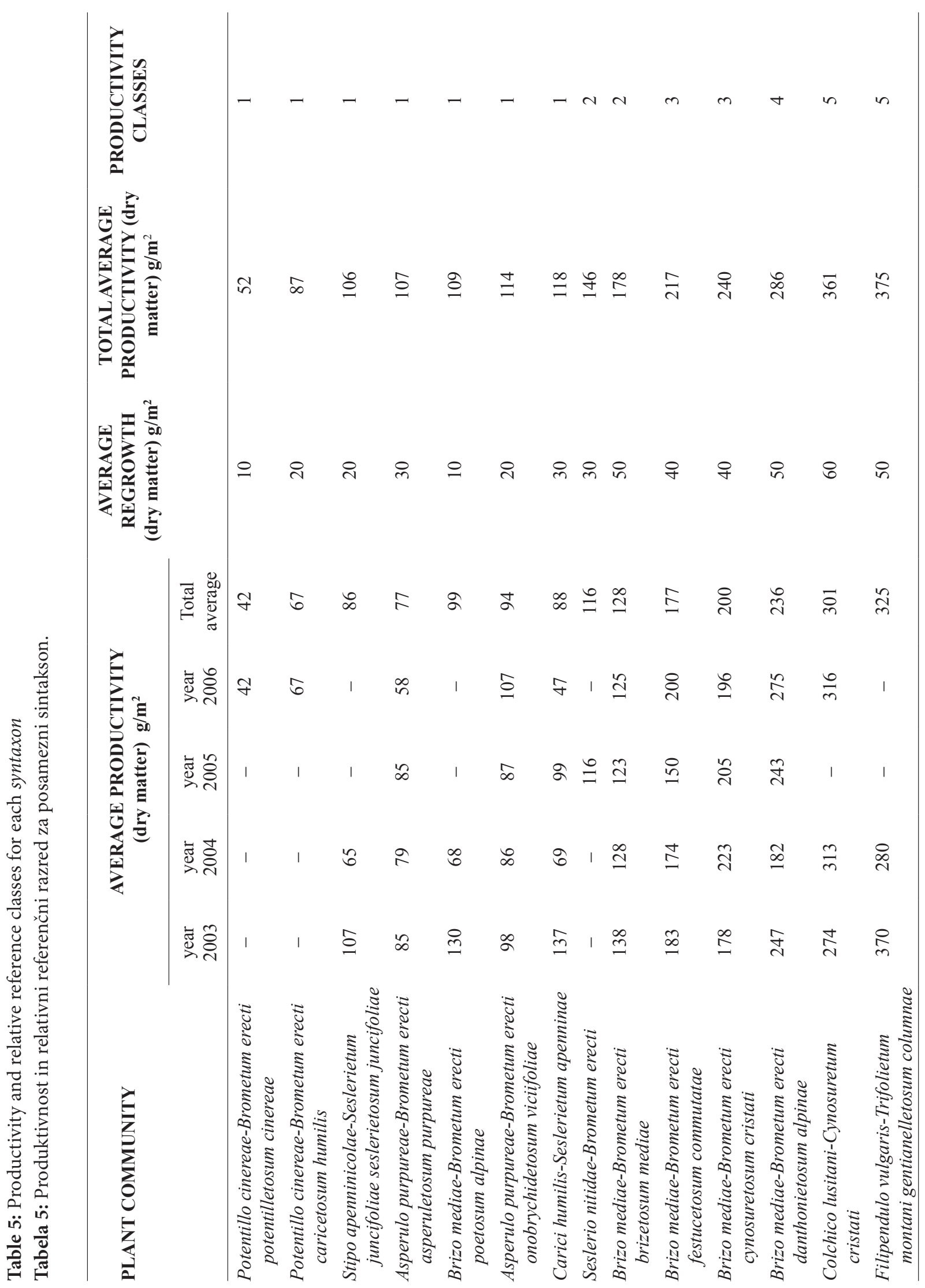




\subsubsection{Productivity}

The productivity results are shown in Table 5 . Also here it is shown that productivity levels of the xeric plant communities found in summit areas are lower than those found on Southern slopes, as are the values of Northern mesophilic plant communities. These show lower productivity levels than the syntaxa typically found in flat areas of valleys or summits.

\subsubsection{Theoretical utilisation coefficient}

The results obtained from the calculation of the theoretical utilisation coefficient $\left(\mathrm{Cu}_{\mathrm{t}}\right)$ of each syntaxon are shown in Table 6 .

Table 6: Theoretical utilisation coefficient (means) for each syntaxon

Tabela 6: Teoretični uporabni koeficient (povprečni) za posamezni sintakson.

\begin{tabular}{ll}
\hline PLANT COMMUNITY & $\mathbf{C u}_{\mathbf{t}}$ \\
\hline $\begin{array}{l}\text { Potentillo cinereae-Brometum erecti } \\
\text { caricetosum humilis }\end{array}$ & 0,40 \\
$\begin{array}{l}\text { Brizo mediae-Brometum erecti poetosum } \\
\quad \text { alpinae }\end{array}$ & 0,42 \\
$\begin{array}{l}\text { Stipo apenninicolae-Seslerietum juncifoliae } \\
\quad \text { seslerietosum juncifoliae }\end{array}$ & 0,48 \\
$\begin{array}{l}\text { Seslerio nitidae-Brometum erecti } \\
\text { Potentillo cinereae-Brometum erecti } \\
\quad \text { potentilletosum cinereae }\end{array}$ & 0,50 \\
$\begin{array}{l}\text { Asperulo purpureae-Brometum erecti } \\
\quad \text { asperuletosum purpureae }\end{array}$ & 0,51 \\
$\begin{array}{l}\text { Carici humilis-Seslerietum apenninae } \\
\text { Asperulo purpureae-Brometum erecti } \\
\quad \text { onobrychidetosum viciifoliae }\end{array}$ & 0,52 \\
$\begin{array}{l}\text { Brizo mediae-Brometum erecti festucetosum } \\
\text { commutatae }\end{array}$ & 0,53 \\
$\begin{array}{l}\text { Brizo mediae-Brometum erecti } \\
\text { cynosuretosum cristati }\end{array}$ & 0,56 \\
$\begin{array}{l}\text { Brizo mediae-Brometum erecti brizetosum } \\
\text { mediae }\end{array}$ & 0,56 \\
$\begin{array}{l}\text { Brizo mediae-Brometum erecti } \\
\text { danthonietosum alpinae }\end{array}$ & 0,64 \\
$\begin{array}{l}\text { Colchico lusitani-Cynosuretum cristati } \\
\text { Filipendulo vulgaris-Trifolietum montani } \\
\text { gentianelletosum columnae }\end{array}$ & 0,76 \\
\hline$\quad$ & 0,66 \\
\hline
\end{tabular}

\subsubsection{Bromatological composition}

Table 7 shows data from the bromatological analysis (chemical composition) of the main plant communities found in the study area.

Table 7: Bromatological characterization

Tabela 7: Bromatološke značilnosti (kemijska sestava).

\begin{tabular}{|c|c|c|c|c|c|}
\hline PLANT COMMUNITY & 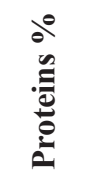 & $\frac{\partial^{0}}{\frac{0}{0}}$ & $\frac{\partial^{\circ}}{2}$ & $\frac{e^{0}}{2}$ & $\frac{\partial^{0}}{\frac{e_{0}}{2}}$ \\
\hline $\begin{array}{l}\text { Brizo mediae-Brometum } \\
\text { erecti cynosuretosum } \\
\text { cristati }\end{array}$ & 10,0 & 1,75 & 30,2 & 53,75 & 6,8 \\
\hline $\begin{array}{l}\text { Brizo mediae-Brometum } \\
\quad \text { erecti brizetosum mediae }\end{array}$ & 11,8 & 3,70 & 37,0 & 49,3 & 6,50 \\
\hline $\begin{array}{l}\text { Brizo mediae-Brometum } \\
\text { erecti danthonietosum } \\
\text { alpinae }\end{array}$ & 11,6 & 1,73 & 33,0 & 55,6 & 6,67 \\
\hline $\begin{array}{l}\text { Filipendulo vulgaris-Trifo- } \\
\quad \text { lietum montani }\end{array}$ & 10,76 & 1,46 & 36,0 & 42,5 & 7,16 \\
\hline $\begin{array}{l}\text { Asperulo purpurea-Brome- } \\
\text { tum erecti onobrychide- } \\
\text { tosum viciifoliae }\end{array}$ & 9,66 & 1,6 & 25,96 & 49,26 & 7,4 \\
\hline $\begin{array}{l}\text { Brizo mediae-Brometum } \\
\text { erecti festucetosum com- } \\
\text { mutatate }\end{array}$ & 10,3 & 1,5 & - & - & 6,7 \\
\hline $\begin{array}{l}\text { Colchico lusitani-Cynosu- } \\
\text { retum cristati }\end{array}$ & 10,2 & 0,95 & 31,3 & 51,7 & 6,7 \\
\hline $\begin{array}{l}\text { Carici humilis-Seslerietum } \\
\text { apenninae }\end{array}$ & 9,5 & 1,9 & 34,05 & 62,6 & 4,65 \\
\hline $\begin{array}{l}\text { Stipo apenninicolae-Sesle- } \\
\text { rietum juncifoliae sesle- } \\
\quad \text { rietosum juncifoliae }\end{array}$ & 9,0 & 1,73 & 39,8 & 59,63 & 5,4 \\
\hline $\begin{array}{l}\text { Asperulo purpurea-Brome- } \\
\text { tum erecti asperuletosum } \\
\text { purpureae }\end{array}$ & 6,9 & 1,95 & 65,0 & 34,7 & 6,2 \\
\hline
\end{tabular}

\subsubsection{Carrying capacity}

The results for the carrying capacity (LSU/ha) of the studied plant communities are presented in Table 8. In general, these results maintain the same pattern of differentiation between the summit communities, slopes and plains, as previously described. 
Table 8: Carrying capacity and relative reference classes for each syntaxon

Tabela 8: Nosilna kapaciteta in relativni referenčni razred za posamezni sintakson.

\begin{tabular}{|c|c|c|}
\hline PLANT COMMUNITY & 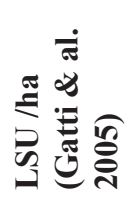 & 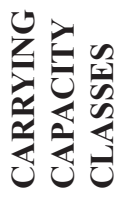 \\
\hline $\begin{array}{l}\text { Potentillo cinereae-Brometum } \\
\text { erecti potentilletosum cinereae }\end{array}$ & 0,18 & 1 \\
\hline $\begin{array}{l}\text { Potentillo cinereae-Brometum } \\
\text { erecti caricetosum humilis }\end{array}$ & 0,24 & 1 \\
\hline $\begin{array}{l}\text { Brizo mediae-Brometum erecti } \\
\text { poetosum alpinae }\end{array}$ & 0,27 & 1 \\
\hline $\begin{array}{l}\text { Stipo apenninicolae-Seslerietum } \\
\text { juncifoliae seslerietosum } \\
\text { juncifoliae }\end{array}$ & 0,37 & 1 \\
\hline $\begin{array}{l}\text { Carici humilis-Seslerietum } \\
\text { apenninae }\end{array}$ & 0,40 & 1 \\
\hline $\begin{array}{l}\text { Asperulo purpureae-Brometum } \\
\text { erecti asperuletosum purpureae }\end{array}$ & 0,41 & 1 \\
\hline $\begin{array}{l}\text { Asperulo purpureae-Brometum } \\
\text { erecti onobrychidetosum } \\
\text { viciifoliae }\end{array}$ & 0,42 & 1 \\
\hline Seslerio nitidae-Brometum erecti & 0,48 & 1 \\
\hline $\begin{array}{l}\text { Brizo mediae-Brometum erecti } \\
\text { festucetosum commutatae }\end{array}$ & 0,77 & 2 \\
\hline $\begin{array}{l}\text { Brizo mediae-Brometum erecti } \\
\text { brizetosum mediae }\end{array}$ & 0,79 & 2 \\
\hline $\begin{array}{l}\text { Brizo mediae-Brometum erecti } \\
\text { cynosuretosum cristati }\end{array}$ & 1,12 & 3 \\
\hline $\begin{array}{l}\text { Brizo mediae-Brometum erecti } \\
\text { danthonietosum alpinae }\end{array}$ & 1,29 & 3 \\
\hline $\begin{array}{l}\text { Colchico lusitani-Cynosuretum } \\
\text { cristati }\end{array}$ & 1,71 & 4 \\
\hline $\begin{array}{l}\text { Filipendulo vulgaris-Trifolietum } \\
\text { montani gentianelletosum } \\
\text { columnae }\end{array}$ & 1,95 & 5 \\
\hline
\end{tabular}

\subsubsection{Total carrying capacity of the pastoral system}

The database associated with the polygons of the phytosociological vegetation map allows for the combination of all data related to the agrozootechnical characteristics of the polygons with the total surface of each polygon family (vegetation association or group of vegetation associations). As an example, relevant data for management purposes are shown in Table 9. This represents the total carrying capacity of the pastoral system of the Umbria-Marches Apennine (Macerata province only) subdivided into bioclimatic belts. Of course this process can be replicated for any territorial fraction within the pastoral system.

Table 9: Total carrying capacity of the studied pastoral system (The total carrying capacity of the pastoral system of the Apennines in the Macerata province is between 84,200 and 135,450 sheep, according to the conversion of 1 LSU/ha into 6 adult ovines - Ronchi 1988).

Tabela 9: Celotna nosilna kapaciteta obravnavanega pašnega sistema (celotna nosilna kapaciteta pašnega sistema Apeninov v provinci Macerata je glede na pretvorbo 1 LSU/ha v 6 odraslih ovc od 84,200 do 135,450 ovc; Ronchi, 1988).

\begin{tabular}{cccccc}
\hline $\begin{array}{c}\text { BIO- } \\
\text { CLMATIC } \\
\text { BELTS }\end{array}$ & $\begin{array}{c}\text { LSU/ha } \\
\text { SOUTH- } \\
\text { ERN } \\
\text { SLOPES }\end{array}$ & $\begin{array}{c}\text { LSU/ha } \\
\text { NORTH- } \\
\text { ERN } \\
\text { SLOPES }\end{array}$ & $\begin{array}{c}\text { LSU/ha } \\
\text { FLAT } \\
\text { AREAS }\end{array}$ & $\begin{array}{c}\text { TOTAL } \\
\text { LSU/ha }\end{array}$ \\
\hline $\begin{array}{c}\text { Upper } \\
\text { Meso- } \\
\text { temperate }\end{array}$ & 149 & 787 & 1840 & 2776 & \\
$\begin{array}{c}\text { Lower } \\
\text { Supra- }\end{array}$ & 721 & 2893 & 3130 & 6744 & \\
temperate & 2323 & 4855 & 4382 & \multicolumn{2}{c}{11560} \\
$\begin{array}{c}\text { Upper } \\
\text { Supra- } \\
\text { temperate }\end{array}$ & 537 & 1989 & 1287 & 4515 & \\
\hline & & 3338 & 1570 & & 6639 \\
\hline
\end{tabular}

\subsection{Gharacterization of the SEASONAL PRODUCTIVITY TRENDS}

The ability to correlate a syntaxon with a certain bioclimatic belt, and thus its particular thermopluviometric characteristics, allows for the modelling of a series of temporal attributes linked to the forage resource, which is essential in managing the system. 


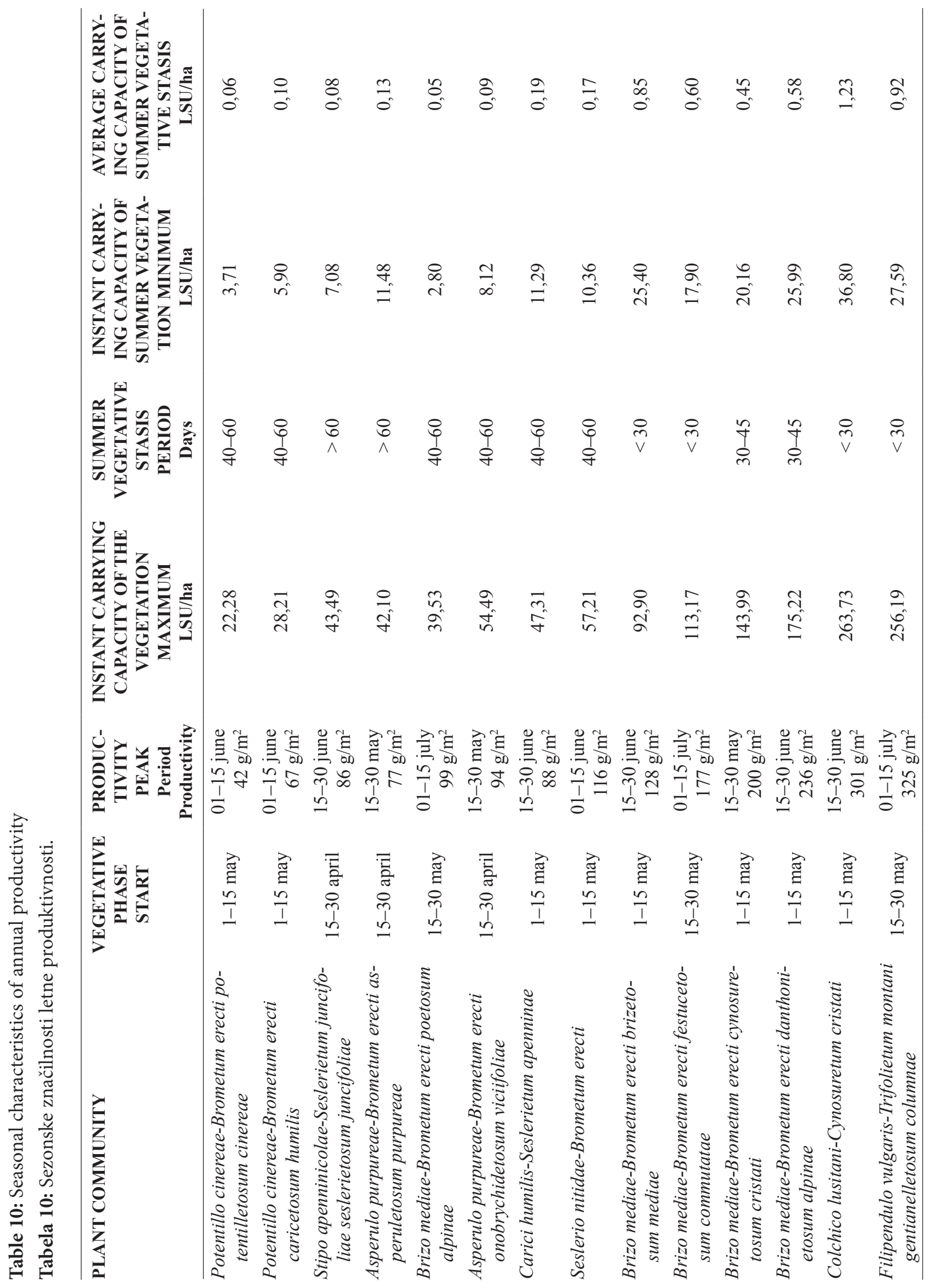




\subsubsection{Vegetative phase}

The vegetative phase, or rather the period in which phytomass is produced, represents a central element in determining the optimal duration for seasonal grazing. There are many direct and indirect methods to obtain these data. Indirect methods lead to preliminary estimates that can subsequently be optimised by using direct data.

In the first case agronomical criteria can be used, which specify the onset of bacterial activity and of the subsequent capacity of the plants to fix nitrogen from the soil. A requirement for this is the existence of mean daily temperature > $10{ }^{\circ} \mathrm{C}$ or, alternatively, minimum daily temperatures $>6{ }^{\circ} \mathrm{C}$ (Conrad \& Pollak 1950, Blasi 1994). The direct methods allow for the creation of productivity curves (Fig. 1), ideally integrating these studies with synphenological data. The start of the vegetative phase can be induced by anthesis of geophytes, immediately preceding or parallel to the vegetative phase of Poaceae and other taxonomic components of grassland (Catorci et al. 2006, Gatti et al. 2007a). Table 10 shows the mean onset of the grassland vegetative phase of the syntaxa within the study area.

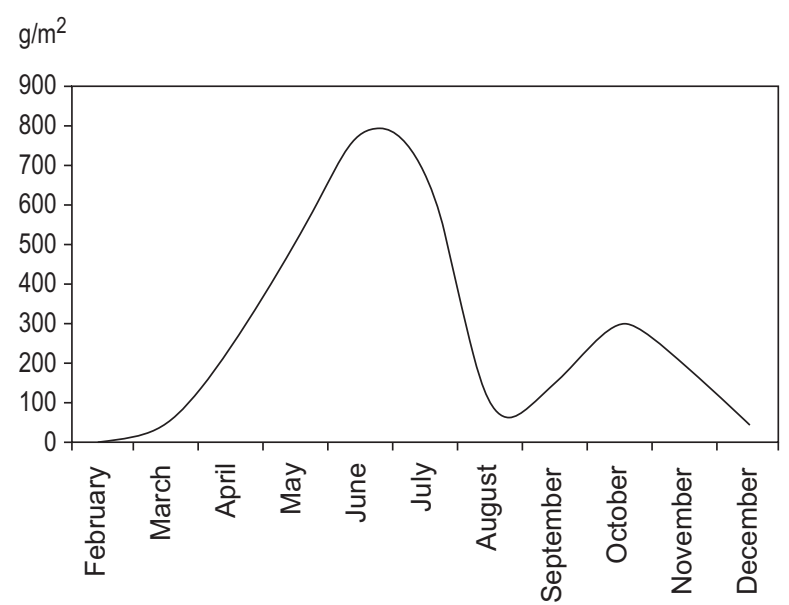

Figure 1: Examples of productivity curves of the northern slopes (Brizo mediae-Brometum erecti brizetosum mediae)

Slika 1: Primeri produktivnostnih krivulj na severnih pobočjih (Brizo mediae-Brometum erecti brizetosum mediae).

\subsubsection{Period of maximum productivity and summer vegetative stasis}

The integration of the climatic analyses with the geo-synphytosociological aspects of the veg- etation allows one to relate the relative data to space both at the seasonal peak of productivity (with the relative theoretical carrying capacity) and during the phase of minimum productivity, or even the vegetative stasis due to a period of summer aridity stress. As before, it is also possible to evaluate the relative theoretical carrying capacity. The availability of these two sets of data represents an important element (together with the mean theoretical carrying capacity of the summer grazing period), for example in defining rotational stocking rates in a pastoral system.

Also in this case it is possible to use indirect and direct methods. In the first case, for example, by verifying whether there is a period of summer aridity or not using the SDS index by $\mathrm{Mi}$ trakos $(1980,1982)$. In the second case, by using data from syn-ecological studies or productivity curves.

Table 10, cited above, shows these parameters for all syntaxa studied.

\subsection{OTHER GHARACTERISTICS OF PASTORAL SYSTEMS}

\subsubsection{Combining productivity and pastoral values (phyto-pastoral value)}

The phytosociological pastoral value and agronomical productivity of a syntaxon express parameters that are not necessarily related to each other. In fact, a syntaxon with high productivity could consist mainly of unpalatable species, whereas a syntaxon with a high pastoral value could be characterised by low productivity. The combination of the two parameters (phyto-pastoral value) is important because it allows one to obtain a comprehensive picture to be used in the design of maps (Cavallero et al. 2002). As shown in Table 11, the productivity classes and pastoral values were compared for each plant community. Using the mean of these values, the sizes of the corresponding intervals were calculated according to Sturges (1926), and each phytocenosis was attributed to its respective reference class with regard to the phyto-pastoral value. This method allows for a fast comparison of the various plant communities and is important especially in evaluation and management of large territories. 
Table 11: Phyto-pastoral values of the studied syntaxa

Tabela 11: Fito-pašne vrednosti obravnavanih sintaksonov.

\begin{tabular}{|c|c|c|c|}
\hline PLANT COMMUNITY & $\begin{array}{l}\text { PRODUCTIVITY } \\
\text { CLASSES }\end{array}$ & $\begin{array}{l}\text { PASTORAL VALUE } \\
\text { CLASSES }\end{array}$ & $\begin{array}{l}\text { PHYTO-PASTORAL } \\
\text { CLASSES }\end{array}$ \\
\hline $\begin{array}{l}\text { Potentillo cinereae-Brometum erecti } \\
\text { potentilletosum cinereae }\end{array}$ & 1 & 1 & 1 \\
\hline $\begin{array}{l}\text { Potentillo cinereae-Brometum erecti } \\
\text { caricetosum humilis }\end{array}$ & 1 & 1 & 1 \\
\hline $\begin{array}{l}\text { Stipo apenninicolae-Seslerietum juncifoliae } \\
\text { seslerietosum juncifoliae }\end{array}$ & 1 & 1 & 1 \\
\hline Carici humilis-Seslerietum apenninae & 1 & 1 & 1 \\
\hline $\begin{array}{l}\text { Asperulo purpureae-Brometum erecti } \\
\text { onobrychidetosum viciifoliae }\end{array}$ & 1 & 2 & 1 \\
\hline Seslerio nitidae-Brometum erecti & 2 & 1 & 1 \\
\hline $\begin{array}{l}\text { Asperulo purpureae-Brometum erecti } \\
\text { asperuletosum purpureae }\end{array}$ & 1 & 3 & 2 \\
\hline $\begin{array}{l}\text { Brizo mediae-Brometum erecti poetosum } \\
\text { alpinae }\end{array}$ & 1 & 3 & 2 \\
\hline $\begin{array}{l}\text { Brizo mediae-Brometum erecti brizetosum } \\
\text { mediae }\end{array}$ & 2 & 3 & 2 \\
\hline $\begin{array}{l}\text { Brizo mediae-Brometum erecti } \\
\text { festucetosum commutatae }\end{array}$ & 3 & 2 & 2 \\
\hline $\begin{array}{l}\text { Brizo mediae-Brometum erecti } \\
\text { cynosuretosum cristati }\end{array}$ & 3 & 3 & 3 \\
\hline $\begin{array}{l}\text { Brizo mediae-Brometum erecti } \\
\text { danthonietosum alpinae }\end{array}$ & 4 & 4 & 4 \\
\hline $\begin{array}{l}\text { Filipendulo vulgaris-Trifolietum montani } \\
\text { gentianelletosum columnae }\end{array}$ & 5 & 2 & 4 \\
\hline Colchico lusitani-Cynosuretum cristati & 5 & 5 & 5 \\
\hline
\end{tabular}

\subsubsection{Combining phyto-pastoral values with floristic values}

Knowledge of particular diversity present in a habitat or a certain territory is now considered a basic necessity in describing environmental systems (Ferrari, 2001). The adoption of appropriate strategies aimed at conserving this diversity must include knowledge and quantification of biodiversity. It is important to remember that there are several indices used to reach such a result. Using the phytosociological database from the Apennines in the Macerata province, a conservation and a rarity index were created, allowing comparison of different plant communities within a territory (Tardella et al. 2007). The results obtained from these analyses are shown in Table 12, in which it can be seen that certain xeric communities, such as Asperulo purpureae-Brometum erecti onobrychidetosum viciifoliae, Asperulo purpureae-
Brometum erecti asperuletosum purpureae, Brizo mediae-Brometum erecti festucetosum commutatae, Brizo mediae-Brometum erecti danthonietosum alpinae have a high rarity index, i.e. contain numerous species within their floristic composition exclusive of the syntaxon. In contrast, another group consisting of Brizo mediae-Brometum erecti brizetosum mediae, Brizo mediae-Brometum erecti poetosum alpinae, Brizo mediae-Brometum erecti festucetosum commutatae, Brizo mediae-Brometum erecti cynosuretosum cristati and Filipendulo vulgaris-Trifolietum montani gentianelletosum columnae is characterised by a high conservation index value.

Given that biodiversity conservation implies conservation of the entire mosaic of plant communities that characterise a territory, comparison of the aforementioned results combined with the phyto-pastoral value allows for the definition of certain priorities and critical points. 
Table 12: Conservation value of studied syntaxa (from Tardella \& al. 2007).

Tabela 12: Ohranitvene vrednosti obravnavanih sintaksonov (iz Tardella \& al. 2007).

\section{PLANT COMMUNITY}

$\begin{array}{cr}\begin{array}{c}\text { FLORISTIC } \\ \text { RARITY } \\ \text { INDEX }\end{array} & \begin{array}{r}\text { FLORIST } \\ \text { CONSERVA } \\ \text { INDEX VA }\end{array} \\ 0,68 & 3,90 \\ 0,92 & 14,30 \\ 0,83 & 19,44 \\ 0,88 & 26,04 \\ 0,88 & 26,04 \\ 0,75 & 29,57 \\ 0,92 & 14,30 \\ 0,89 & 72,60 \\ 0,80 & 72,60 \\ 0,92 & 76,20 \\ 0,80 & 72,60 \\ 0,89 & 72,60 \\ 0,71 & 42,39 \\ 0,80 & 3,75\end{array}$

For example, within the study area, Asperulo purpureae-Brometum erecti, has a high rarity index but a low phyto-pastoral value. On the one hand, this shows the importance of conserving these plant communities. On the other hand, given the low density of grazing animals, these plant communities are more likely to be abandoned, as they are less interesting for animal nutrition. With regard to management, it may be necessary to place economic priority on zootechnical development in order to sustain pasture on arid and less productive grasslands. In this way colonisation through shrubs and eliophilic trees can be avoided.

\section{DISCUSSION}

As seen in the flow chart in Fig. 2, phytosociological analysis can be used to create models aimed at describing pastoral landscapes, their functions and their priorities. Following this procedure, phytosociological maps (basic and derived) can be created. Due to the spatial characterization of collected data this information can be applied to all homogeneous polygons in terms of phytosociology and correlated to the intrinsic floristic-structural characteristics of the studied association. This method allows one to proceed along two main conceptual pathways, defined as indirect and direct, respectively. The indirect method is based on phytosociologically derived

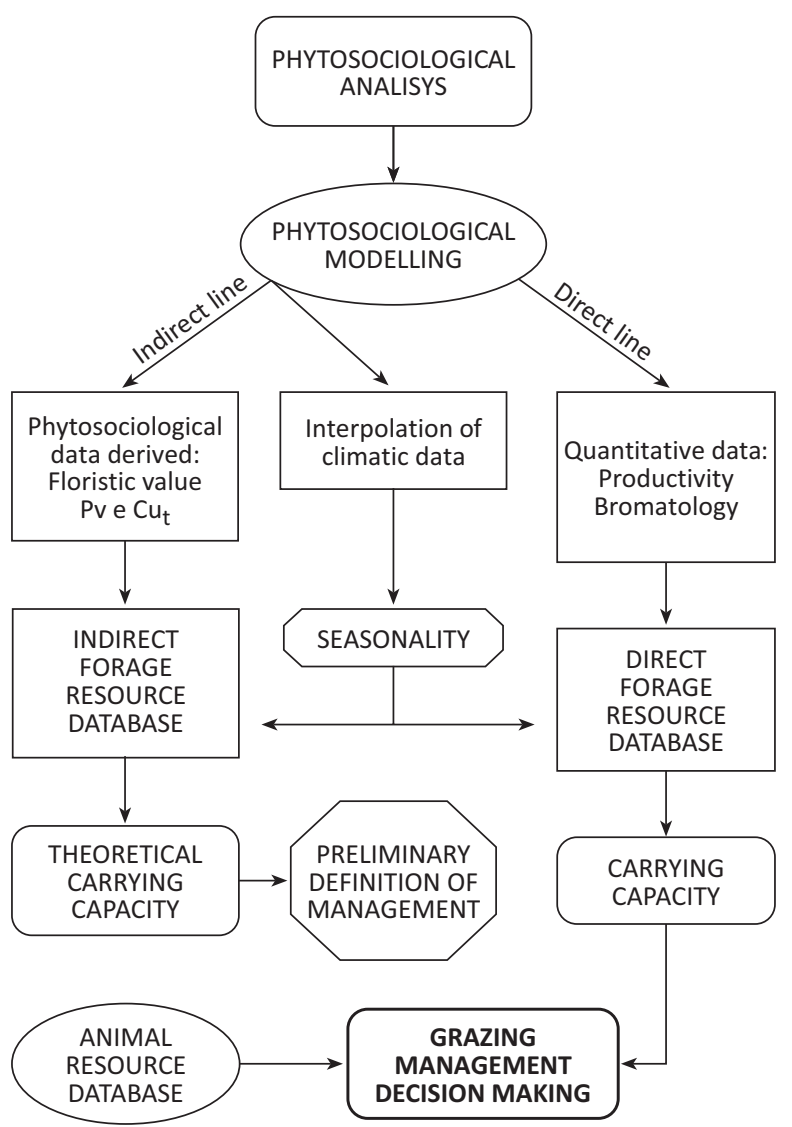

Figure 2: Grazing management decision making on the basis of the phytosociological analysis and modelling Slika 2: Odločanje o pašnem gospodarjenju na podlagi fitosociološke analize in modeliranja. 
data (floristic significance, $\mathrm{Vp}$ e $\mathrm{Cu}$ ), thus making it possible to calculate the theoretical carrying capacity and define a preliminary grazing management strategy.

Using the direct procedure, by means of quantitative analysis of productivity parameters and bromatological characterization, a definition of the actual carrying capacity can be obtained.

The correlation of these parameters with seasonality and the qualitative elements that result from the direct analysis enables a first definition of a management strategy for the pastoral system.

Overlapping the results obtained from the analysis of the forage resource with those of the animal population, a first definition of the main strategies for grazing management can be obtained, an essential planning element for the conservation and maintenance of grassland ecosystems.

\section{GONCLUSIONS}

Modelling of forage resources and pastoral systems through an integrated approach has shown great potential in on-field application by combining landscape ecology, vegetation and agrozootechnical sciences. These results are important in terms of biodiversity conservation and in defining the main strategies for pastoral systems management.

Furthermore, this process has shown how the hierarchical organisation of a database enables, in such a long and complex process, the progressive gathering of knowledge, both in qualitative and quantitative terms. This process avoids long periods of research prior to making management decisions, followed by a more detailed management strategy based on improved knowledge. In particular, this method makes it posible to obtain a first general overview of the forage resource using the theoretical data linked to the phytosociological interpretation of the territory. Subsequently, this overview can be enhanced with actual quantitative data, offering also a qualitative dimension coming from the phytosociological aspects.

\section{ACKNOWLEDGEMENT}

This study was developed within the project "Eco-compatible production and evaluation of typical products of the Marches Apennines" carried out with financial support from the Marches Region (Fund CIPE 2004).

\section{REFERENCES}

Agnelli, A., Allegrezza, M., Biondi, E., Cocco, S., Corti, G. \& Pirchio, F. 2008: Pedogenesi e paesaggio vegetale: il ruolo dell'esposizione. Fitosociologia 45 (1): 23-28.

Allegrezza, M. 2003: Vegetazione e paesaggio vegetale della dorsale del Monte San Vicino (Appennino centrale). Fitosociologia 40 (1) Suppl. 1: 3-118.

Allen, T.H.F. \& Starr, T.B. 1982: Hierarchy, Perspectives for Ecological Complexity. The University of Chicago Press, Chicago, $310 \mathrm{pp}$.

Bagella, S. 2001: Valore pastorale delle associazioni vegetali: un esempio di applicazione nell'Appennino Uumbro-Marchigiano(Italia). Fitosociologia 38 (1): 153-165.

Bagella, S. \& Roggero, P.P., 2004: Analisi spaziotemporale della produzione di praterie secondarie nell'Appennino Umbro-Marchigiano (Italia). Inf. Bot. Ital. 35 (2): 309-320.

Baldoni, M.A., Ballelli, S., Biondi, E., Catorci, A. \& Orsomando, E. 1996: Studio fitosociologico delle formazioni prative del Monte Subasio (Appennino Umbro-Marchigiano). Doc. Phytosoc. XVI: 427-448.

Bakker, J. P. 1998: The impact of grazing on plant communities. In: WallisDevries, M.F., Bakker, J.P. \& Van Wieren, S.E (eds): Grazing Conservation Management. Kluwer Academic Publishers, London, pp. 137-184.

Biondi, E., 1996: L'analisi fitosociologica nello studio integrato del paesaggio. Avances en Fitosociologia: 13-22.

Biondi, E. 2001: Paesaggio vegetale e potenzialità pastorali. In: Atti del 36 simposio internazionale di zootecnia "Prodotti di origine animale: qualità e valorizzazione del territorio". Portonovo (Ancona) 27 aprile 2001, 1: 5-22, Greppi \& En. eds.

Biondi, E. \& Ballelli, S. 1995: Le praterie del Monte Coscerno e Monte Civitella (Appennino Umbro-Marchigiano- Italia centrale). Fitosociologia 30: 91-121.

Biondi, E., Allegrezza, M. \& Zuccarello, V. 2005: Syntaxonomic revision of the Apennine grassland belonging to Brometalia erecti, and an analysis of their relationships with the xerophi- 
lous vegetation of Rosmarinetea officinalis. Phytocoenologia 35 (1): 129-163.

Biondi, E., Baldoni, M.A. \& Talamonti, M.C. 1995: Il fitoclima delle Marche. In: Atti del convegno "Salvaguardia e gestione dei beni ambientali nelle Marche" (Ancona, 8-9 aprile 1991). Ancona, Accademia di scienze, lettere ed arti: 21-70.

Biondi, E., Casavecchia, S. \& Guerra, V. 2006: Analysis of vegetation diversity in relation to the geomorphological characteristics in the Salento coasts (Apulia-Italy). Fitosociologia 43 (1): 25-38.

Biondi, E., Feoli, F. \& Zuccarello, V. 2004a: Modelling Environmental Responses of Plant Associations: A Review of Some Critical Concepts in Vegetation Study. Critical Reviews in Plant Sciences 23 (2): 149-156.

Biondi, E., Pinzi, M. \& Gubellini, L. 2004b: Vegetazione e paesaggio vegetale del Massiccio del Monte Cucco (Appennino centrale, Dorsale Umbro-Marchigiana). Fitosociologia 41(2) Suppl. 1: 3-81.

Bittante, G., Andrighetto, I. \& Ramanzin, M., 1990: Fondamenti di zootecnia. Miglioramento genetico, nutrizione e alimentazione. Liviana Editrice, Padova. 244-293.

Bittante, G., Andrighetto, I. \& Ramanzin, M. 1993: Tecniche di produzione animale. Liviana Editrice, Padova, 490 pp.

Blaschka, T. 2001: Multiskalare bildanalyse zur umsetzung des Patch-matrix-konzepts in der landschaftsplanung. Naturschtz und landschaftsplanung 2/3: 84-89.

Blasi, C. 1994: Fitoclimatologia del Lazio. Fitosociologia 27: 151-175.

Blasi, C., Smiraglia, D. \& Carranza, M.L. 2003: Analisi multitemporale del paesaggio e classificazione gerarchica del territorio: il caso dei Monti Lepini (Italia centrale). Inf. Bot. Ital. 35 (1): 31-40.

Blasi, C., Carranza, M., Frondoni, R. \& Rosati, L. 2000: Ecosystem classification and mapping: a proposal for Italian landscape. Applied Vegetation Science 3: 233-242.

Bonanomi, G. \& Allegrezza, M. 2004: Effetti della colonizzazione di Brachypodium rupestre (Host) Roemer et Schultes sulla diversità di alcune fitocenosi erbacee dell'Appennino centrale. Fitosociologia 41 (2): 51-69.

Braun-Blanquet, J. 1931: Pflanzensoziologie. Grundzüge der Vegetationskunde. Springer Verlag, Wien.
Cano, E., García-Fuentes, A., Torres, J.A., Salazar, C., Melendo, M., Pinto-Gomes, C. \& Valle, F. 1997: Phytosociologie appliquée à la planification agricole. Colloques Phytosociologiques XXVII: 1007-1022.

Catorci, A., Cesaretti, S. \& Marchetti, P. (eds.) 2007a: Vocazionalità del territorio della Comunità Montana di Camerino per la produzione di biomasse solide agro-forestali ad uso energetico. L'uomo e l'ambiente 47. Tipografia Arte Lito, Camerino, 75 pp.

Catorci, A., Gatti, R. \& Ballelli, S. 2007b: Studio fitosociologico della vegetazione delle praterie montane dell'Appennino maceratese. In: Catorci, A. \& Gatti, R. (eds.): Le praterie montane dell'Appennino maceratese. Braun-Blanquetia 42: 101-144.

Catorci, A., Gatti, R. \& Vitanzi, A. 2006: Relationship between phenology and above-ground phytomass in a grassland community in central Italy. In: Gafta, D. \& Akeroyd, J.R. (eds.): Nature conservation. Concepts and Practice. Sprinter, pp. 309-327.

Cavallero, A., Rivoira, G. \& Talamucci, P., 2002: Pascoli. In: Baldoni, R. \& Giardini, L. (eds.): Coltivazioni erbacee-foraggere e tappeti erbosi. Patron editore, Bologna, pp. 239-294.

Conrad, V. \& Pollak, L. W. 1950: Methods in climatology. Harvard University Press. Cambridge, $459 \mathrm{pp}$.

Corrall, A.J. \& Fenlon, J.S. 1978: A comparative method for describing the seasonal distribution of production from grasses. Journal of Agricultural Science 91: 61-67.

Cremaschi, M. \& Rodolfi, G. 1991: Il suolo. Roma, La Nuova Italia Scientifica Editrice, 267 pp.

Cutini, M, Catorci, A., Gatti, R., Paura, B. \& Acosta, A. 2007: Analisi delle relazioni tra parametri geomorfologici e comnità prative in ambiente montano (Appennino umbro-marchigiano). In: Catorci, A. \& Gatti, R. (eds.): Le praterie montane dell'Appennino maceratese. Braun-Blanquetia 42: 159-164.

Daget, Ph. \& Poissonet, T. 1969: Analyse phytologique des prairies. INRA, Montpellier Document 48 .

Delpech, R. 1960: Critères de jugement de la valeur agronomique des prairies. Fourrages 4: 83-98.

Ercole, S., Acosta, A. \& Blasi, C. 2005: Parametri ambientali e vegetazione: analisi quantitativa di variabili ambientali nell'ambito di uno 
studio fitosociologico. Inform. Bot. Ital. 37: 494-495.

Farina, A. 2001: Ecologia del paesaggio. Principi, metodi ed applicazioni. UTET Libreria, Torino, $673 \mathrm{pp}$.

Ferrari, C. 2001: Biodiversità dall'analisi alla gestione. Zanichelli, 144 pp.

Filasi, L., Acosta, A., Bottini, D., Dowgiallo, G. \& Blasi, C. 2004: Le comunità vegetali del promotorio del Circeo in relazione al suolo. In: Amato, M., Migliozzi, A. \& Mazzoleni, S.: Il sistema suolo vegetazione. Liguori Editore, pp. 253-262.

Floret, C. \& Le Floch, E. 1983: Phytomasse et production végétale en Tunisie présaharienne. Acta Oecol./Oecol. Plant. 4 (18) 2: 133-152.

Foglia, M., Sparvoli, D. \& Catorci, A. 2007: Analisi multitemporale dell'uso del suolo della dorsale appenninica marchigiana nel XIX e XX secolo. In: Catorci A, Gatti R. (eds.): Le praterie montane dell'Appennino maceratese. Braun-Blanquetia 42: 47-72.

Francalancia, C., Galli, P. \& Paradisi, L. 1995: Variazioni nella composizione floristica dei prati a Cynosurus cristatus L. delle alte Valli di Tazza e di Fematre (Appennino Marchigiano) in rapporto alle pratiche colturali. Fitosociologia 29 (1): 89-94.

Gatti, R. \& Catorci, A. 2005: Contributo alla caratterizzazione dei pascoli alto-collinari dell'Appennino Umbro-Marchigiano a fini zootezcnici (Prati di Gagliole e Monti Rogedano-Puro). Progetto Docup ob. 2 "Rete didattica, Natura, Ambiente, Territorio dell' Appennino umbro-marchigiano". Regione Marche, Aula Verde Valleremita, CEA Valle dei Grilli e dell'Elce, Dip. di Botanica ed Ecologia, Unicam. Arti Grafiche Gentile, Fabriano, 52 pp.

Gatti, R. \& Catorci, A. 2007: Prima caratterizzazione dei pascoli montani dell'Appennino maceratese ai fini zootecnici. In: Catorci A, Gatti R. (eds.): Le praterie montane dell'Appennino maceratese. Braun-Blanquetia 42: 267-272.

Gatti, R., Carotenuto, L. \& Catorci, A. 2007a: Sinfenologia di alcuni syntaxa prativi dell'Appennino umbro-marchigiano (Italia centrale). In: Catorci A, Gatti R. (eds.): Le praterie montane dell'Appennino maceratese. Braun-Blanquetia 42: 179-202.

Gatti, R., Galliano, A. \& Catorci, A. 2007b: Valore pastorale delle praterie montane dell'Appennino maceratese. In: Catorci A, Gatti R. (eds.):
Le praterie montane dell'Appennino maceratese. Braun-Blanquetia 42: 247-253.

Gatti, R., Vitanzi, A., Cesaretti, S. \& Catorci, A. 2007c: Contributo alla quantificazione della fitomassa epigea di alcuni pascoli dell'Appennino umbro-marchigiano (Italia centrale). In: Catorci A, Gatti R. (eds.): Le praterie montane dell'Appennino maceratese. Braun-Blanquetia 42: 255-266.

Gatti, R., Carotenuto, L., Vitanzi, A., Pieruccini, P. \& Catorci, A. 2005: Plant biodiversity conservation and sustainable grazing in mountain grasslands: a case study in Umbria-Marche Apennines (Central Italy). Ecologia: Atti del Congresso Nazionale della Società Italiana di Ecologia (S.It.E.), Torino 12-14 settembre 2005.

Géhu, J.M. 1988: Sur la notion de cellules paysageres isofunctionnelles. Colloques Phytosociologiques.

Géhu, J.M. \& Rivas-Martinez S., 1981: Notions fondamentales de phytosociologie. Ber. Int. Simp. Int. Vereinigung Vegetationsk: 5-33.

Géhu, J.M., Bouzille, J.B., Bioret, F., Godeau, M., Botineau, M., Clement, B., Touffet, J. \& Lahondere, C. 1991: Approche paysagere symphytosociologique des marais littoraux du centre-ouest de la France. Colloques phytosociologique. Phytosociologie et paysages, XVII : 109-127.

Gratani, L., Rossi, A., Crescente, M.F. \& Frattaroli, A.R. 1999: Ecologia dei pascoli di Campo Imperatore (Gran Sasso d'Italia) e Carta della biomassa vegetale. Braun-Blanquetia 16: 227247.

Grayson, B. 1999: The agricultural perspective. In: Crofts, A. \& Jefferson R.G.: The lowland grassland management handbook. English Nature/The wildlife trusts of the Royal Society for Nature Conservation, London, chapter 4: 1-37 pp.

Grime, J.P. 1973: Competitive exclusion in herbaceous vegetation. Nature 242: 344-347.

Grime, J.P. 2001: Plant strategies, Vegetation Processes and Ecosystem Properties. John Wiley and Sons Ltd, London, $417 \mathrm{pp}$.

Hodgson, J. \& Illius, A.W. 1998: The Ecology and Management of Grazing Systems. CAB International, Wallingford, $480 \mathrm{pp}$.

King, A.W. 1977: Hierarchy Theory: A guide to system structure for wildlife biologists. In: Bissonette, A. (eds.): Wildlife and Landscape Ecology. Effects of Pattern and Scale. Springer, New York, pp. 1717-1725. 
Miles, J. 1985: The pedogenic effects of different species and vegetation types and the implications of succession. Journal of soil science 36 : 571-584.

Miles, J. 2004: Le dinamiche delle relazioni suolo-vegetazione negli ecosistemi naturali. In: Amato, M., Migliozzi, A. \& Mazzoleni, S.: Il sistema suolo vegetazione. Liguori Editore, pp. 125-136.

Mitrakos, K. 1980: A theory for Mediterranean plant life. Acta Oecologica/Oecologia Plantarum, 1(15), 3: 245-252.

Mitrakos, K. 1982: Winter low temperatures in mediterranean-type ecosystems. Ecologia Mediterranea, VIII (1-2): 95-102.

O’Neill, R.V. \& King, A. W. 1988: Homage to St. Michael: or, Why are there so many books on scale? In: Tereson, D.L. \& Parker, V.T. (eds): Ecological Scale. Theory and Applications. Columbia University Press, New York, pp. 3-15.

Orsomando, E., Catorci, A., Pitzalis, M. \& Raponi, M. 1999: Carta fitoclimatica dell'Umbria (scala 1: 200.000). Regione dell'Umbria. Area Assetto del Territorio e P.U.T., Dip. di Botanica ed Ecologia, Univ. di Camerino. Ist. di Ecologia Agraria, Univ. di Perugia. S.El.Ca. Firenze.

Ozenda, P. 1982: Les Végétaux dans la biosphere. Doin Editeurs, Paris, France, 431 pp.

Pedrotti, F. 2004: Cartografia geobotanica. Pitagora Editrice Bologna. S.El.C.A., Firenze, 236 pp.

Persson, S. 1984: Vegetation development after the exclusion of grazing cattle in a meadow area in the south of Sweden. Vegetatio, 55: 65-92.

Pieruccini, P. 2007: Suoli e geomorfologia delle praterie montane nell'Appennino UmbroMarchigiano. In: Catorci, A. \& Gatti, R. (eds.): Le praterie montane dell'Appennino maceratese. Braun-Blanquetia 42: 19-36.

Podani, J. 2001: Syntax 2000 Computer program for data analysis in ecology and systematics. Budapest.

Pott, R. 1998: Effects of human interference on the landscape with special reference to the role of grazing livestock. In: WallisDevries, M.F., Bakker, J.P. \& Van Wieren, S.E (eds.): Grazing Conservation Management. Kluwer Academic Publishers, London, pp. 107-134.

Redecker, B., Finck, P., Härdtle, W., Riecken, U. \& Schröder, E. 2002: Pasture Landscapes and Nature Conservation. Springer-Verlag Berlin, $435 \mathrm{pp}$.

Regione Marche, 1991: L'ambiente fisico delle
Marche. Geologia Geomorfologia Idrogeologia. Giunta Regionale. Assessorato Urbanistica e Ambiente, Ancona, 255 pp.

Rivas-Martinez, S. 2005: Avances en Geobotanica. http://www.globalbioclimatics.org

Roggero, P. P., Bagella, S. \& Farina, R. 2002: Un archivio dati di Indici specifici per la valutazione integrata del valore pastorale. Rivista di Agronomia 36 (2): 149-156.

Ronchi, B. 1988: Zootecnica nelle regioni di montagna. Athene editrice, Roma, $221 \mathrm{pp}$.

Sánchez Rodríguez, E., Amor Morales, Á. \& Ladero Álvarez, M., 2006: Estudio fitosociólogico y bromatológico de los pastizales con interés ganadero en la provincia de Salamanca (España). Studia Botanica 25: 9-61.

Sarno, R., Talamucci, P., Cavallero, A. \& Stringi, L. (eds.) 1989: Distribuzione della produzione dei pascoli in ambienti marginali italiani. Guida alla valutazione della produttività. Progetto Finalizzato CNR-IPRA Aree Marginali, Palermo, pp. 175.

Sturges, H. 1926: The choice of a class-interval. Journal of American Statistical Associations 21 (153): 65-66.

Tainton, N. M., Morris, C. D. \& Hardy, M. B. 1996: Complexity and stability in grazing systems. In: Hodgson, J. \& Illius, A. W. (eds.). The Ecology and Management of Grazing Systems. Cab International, UK, pp. 275-299.

Tardella, F.M, Ballelli, S., Gatti, R. \& Catorci, A. 2007: Diversità floristica delle praterie montane dell'Appennino maceratese. In: Catorci, A. \& Gatti, R. (eds.): Le praterie montane dell'Appennino maceratese. Braun-Blanquetia 42: 145-158.

Theurrilat, J.P. 1992: L'analyse du paysage végétal en symphytocoenologie: ses niveaux et leurs domains spatiaux. Bull. Ecol. 23 (1-2): 83-92.

Tomaselli, R. 1956: Introduzione allo studio della fitosociologia. Industria Poligrafica Lombarda, Milano, 319 pp.

WallisDeVries, M.F \& Van de Koppel, J. 1998: The role of scientific models. In: WallisDeVries M.F., Bakker J.P., Van Wieren S.E.. (eds.): Grazing Conservation Management. Kluwer Academic Publishers, London, pp. 321-340.

Recieved 5. 2. 2009

Revision recieved 19. 8. 2009 Accepted 28. 8. 2009 